\title{
Prognóza pacienta s ischemickou chorobou srdeční aneb na čem záleží
}

\author{
doc. MUDr. Tomáš Kovárník, Ph.D. \\ II. interní klinika VFN a 1. LF UK, Praha
}

Doc. Kovárník rozebral ve své přednášce postupy rádné prevence koronárních príhod u pacientů s ICHS. Zdůraznil zejména nutnost snížení nadměrné aktivace sympatoadrenálního systému, kterou snadno identifikujeme podle zvýšené tepové frekvence a vysokého tlaku krve, a také dosažení nízké hladiny LDL cholesterolu. Na místě je léčba inhibitory systému RAAS a $\beta$-blokátory spolu s podáváním statinů, popř. v kombinaci s ezetimibem a inhibitory PCSK9. Doc. Kovárník poukázal na časté nedostatečné dávkování těchto prípravků zjištěné v českém průzkumu. Dlouhodobé snížení krevního tlaku a tepové frekvence má přitom př́znivý kumulativní dopad na prognózu pacientů s ICHS a dosažená hladina LDL cholesterolu pod 1,8 mmol/I může navodit dokonce regresi koronární aterosklerózy. U pacientů po akutním koronárním syndromu s vysokým rizikem ischemie a bez zvýšeného rizika krvácení je př́nosem také dlouhodobá duální protidestičková léčba. Vysoký počet předepsaných tablet ke každodennímu uživání spolu s asymptomatičností rizikových faktorů aterosklerózy jsou přičinou nízké adherence pacientů k léčbě. Nedodržování preventivní léčby má prokázaný vliv na výskyt koronárních př́hod a je významnou překážkou při zlepšování prognózy pacientů s ICHS. Pacient by měl proto užívat co nejnižší počet tablet, což znamená vysazení medikace bez prokázaného př́nosu a využití fixních kombinací.

\section{Definice ischemické choroby srdeční}

Ischemická choroba srdeční (ICHS) je dána prítomností koronární aterosklerózy provázené ischemií myokardu. Její manifestaci rozdělujeme na akutní koronární syndromy (ACS), zahrnující STEMI (infarkt myokardu s elevací úseku ST), NSTEMI (infarkt myokardu bez elevace úseku ST), nestabilní anginu pectoris (AP) a náhlou srdeční smrt, a na chronické koronární syndromy, zahrnující stabilní AP, ischemickou dysfunkci levé komory a němou ischemii myokardu.

\section{Rozsah aterosklerotického postižení jako prediktor koronárních příhod}

Průběh ICHS je při optimální kontrole rizikových faktorů, úpravě životního stylu a prípadně provedení revaskularizace mírně progredující. Pokud jsou ale uvedené intervence suboptimální, dochází k opakovaným koronárním príhodám a prognóza pacienta se značně zhoršuje. Mortalita pacientů se stabilní AP je 1-2 \%. V prípadě nestabilní AP nebo non-Q infarktu myokardu (IM) je mortalita hospitalizovaných pacientů 10 \%. Před přijetím do nemocnice umírá 40-50 \% pacientů, převážně z důvodu fibrilace komor. Opakované koronární príhody po prodělaném IM mohu být zapříčiněny stejnou aterosklerotickou lézí, častěji ale bývá jejích původem léze jiná (Varenhorst, 2018). Přítomnost více lézí (postižení více koronárních cév) je nejsilnějším prediktorem výskytu další ACS. Lékař provádějící koronární intervenci by proto měl vždy uvést do zprávy rozsah aterosklerotického postižení cév. Je doloženo, že objem aterosklerotických plátů a jejich složení je lineárně závislé na hladině LDL cholesterolu (Tsujita, 2015). Snižení hladiny LDL cholesterolu vede k zmenšení objemu plátů a navíc bylo prokázáno, že koreluje s výskytem koronárních příhod, Obr. 1.
(CTT 2010). Ke vzniku aterosklerotických plátů vede dysfunkce endotelu. Jde o stav navozený špatným životním stylem, chronickým stresem a psychosociálními faktory, kdy dochází ke zmenšování endotelových buněk a rozvolňování jejich vzájemných junkcí. Cholesterol se tak snadno dostává do cévní stěny nejen přes změněné endotelie, ale i prímo přes narušené zvětšující se rozestupy mezi těmito buňkami (Mundi, 2018).

\section{Antiagregační léčba}

$\checkmark$ prevenci opakovaných ACS podáváme pacientům antiagregační léčbu. Nelze ale zapomínat na to, že tato léčba zvyšuje riziko krvácivých komplikací, které znamenají nejen snížení krevního zásobení, zhoršenou možnost rehabilitace, ale i zvýšení výskytu ischemických př́hod v důsledku aktivace koagulačního systému a vzniku intrakoronární trombózy. Krvácení je tak jedním z faktorů, které zvyšují mortalitu po koronární intervenci. Zatímco mortalita hospitalizovaných pacientů s ACS bez krvácení je 1,9\%, pokud dojde ke krvácení, zvyšuje se na 5,3\% (Chhatriwalla 2013). Při akutní i následné péči je proto třeba posoudit poměr rizika ischemie a krvácení. Pacienti s vysokým rizikem ischemie bez zvýšeného rizika krvácení profitují z dlouhodobé duální protidestičkové léčby. Jak uvádějí doporučení ESC/EASTS (Evropská kardiologická společnost/ Evropská asociace kardiochirurgů a hrudních chirurgů) (Neumann, 2019), u takových pacientů je vhodné upřednostnit ticagrelor (60 mg 2× denně) přidaný ke kyselině acetylasalicylové (ASA) před clopidogrelem a prasugrelem. Pacient s vysokým rizikem aterotrombotických příhod je pritom definován věkem $>50$ let $+\geq 1$ z následujících faktorů: věk $>65$ let, diabetes mellitus vyžadující farmakoterapii, dalši IM v anamnéze, vícečetné postižení koronárních tepen, chronická renální insuficience (clearance 
Obr. 1. Sniženi hladiny LDL-cholesterolu koreluje s výskytem KV príhod (CTT 2010)

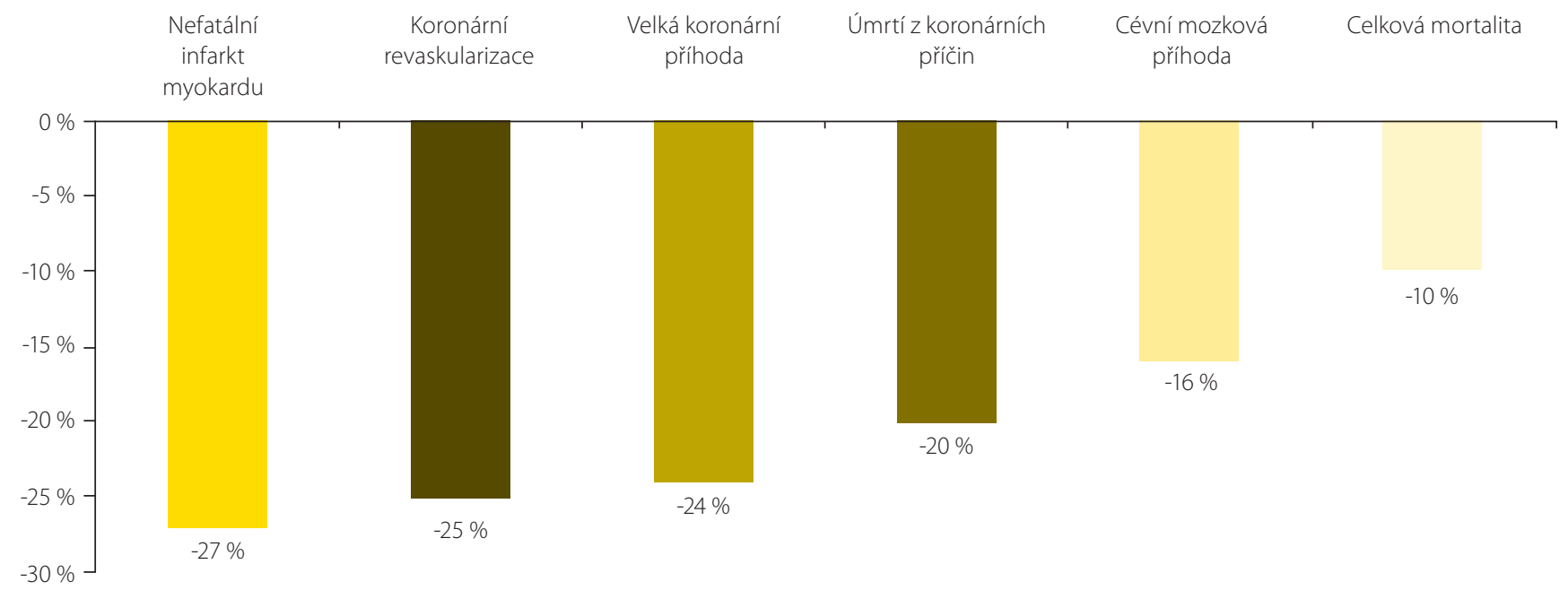

kreatininu $<60 \mathrm{ml} / \mathrm{min}$ ). Pacient dále nesmí uživat antikoagulační léčbu, mít aktivní patologické krvácení, ani předchozí intrakraniální krvácení.

\section{Nadměrná aktivace sympatoadrenálního systému}

Sympatoadrenální systém (SAS) a systém renin-angiotenzin-aldosteron (RAAS) jsou dva systémy nezbytné pro přežití, které vzájemně spolupracují. U osob s ICHS, hypertenzí a diabetem ovšem dochází k jejich chronické hyperaktivaci. Akumulace rizikových faktorů vedoucí ke zvýšení cévního věku je pak príčinou manifestace aterosklerotických chorob, ale také poruch paměti a zvýšeného rizika maligních nádorů. Logická je tedy intervence a dlouhodobá kompenzace kardiovaskulárních (KV) rizikových faktorů, která při dlouhodobém pưsobení sniží výskyt nefatálních príhod a zlepší prognózu pacientů.

Př́mé měření aktivity sympatiku v laboratoři je možné, ale velmi nákladné a nepraktické. Jednoduchými ukazateli zvýšené aktivity sympatiku jsou vysoká tepová frekvence a krevní tlak. Studie, která hodnotila souvislost vysokého krevního tlaku a tepové frekvence s výskytem KV príhod, ukázala dle očekávání nejvyšší výskyt u osob, které mají současně zvýšené oba parametry. Z jejích výsledků je ale také patrný vyšší výskyt KV príhod u jedinců se zvýšenou tepovou frekvencí a normálním tlakem krve v porovnání s osobami se zvýšeným tlakem krve a normální tepovou frekvencí (Obr. 2.) (Julius, 2012). Tachykardie je po vyloučení anémie a thyreotoxikózy markerem zvýšené aktivity sympatiku. Vede ke zkrácení plnění koronárních tepen a akcentuje koronární aterosklerózu.

Pro ovlivnění tonu sympatiku máme z medikace $k$ dispozici $\beta$-blokátory a blokátory RAAS, tedy inhibitory ACE a blokátory AT1 receptorů. Z $\beta$-blokátorů je třeba volit kardioselektivní látky. Kombinace těchto léků vede k významnému snížení klinických príhod. Metaanalýza placebem kontrolovaných studií ukázala pokles složeného sledovaného parametru zahrnujícího celkovou i KV mortalitu a nefatální IM o 20 \% při podávání ACEl s $\beta$-blokátorem v porovnání se samotným $\beta$-blokátorem (Brugts, 2016). Porovnání ACEl a blokátorů AT1 receptorů v kombinaci s $\beta$-blokátory ukázalo významně nižší celkovou i KV mortalitu při volbě ACEl, Obr. 3. (Kim, 2019). Důvodem je zřejmě zvýšená hladina bradykininu, kterou ACEl navozují a která snižuje zátěž levé komory, působí vazodilatačně a vazoprotektivně. Tato třída inhibitorů RAAS by tedy měla být upřed-
Obr. 2. Souvislost frekvence (TF) a tlaku (TK) se vznikem KV príhod (Julius, 2012)

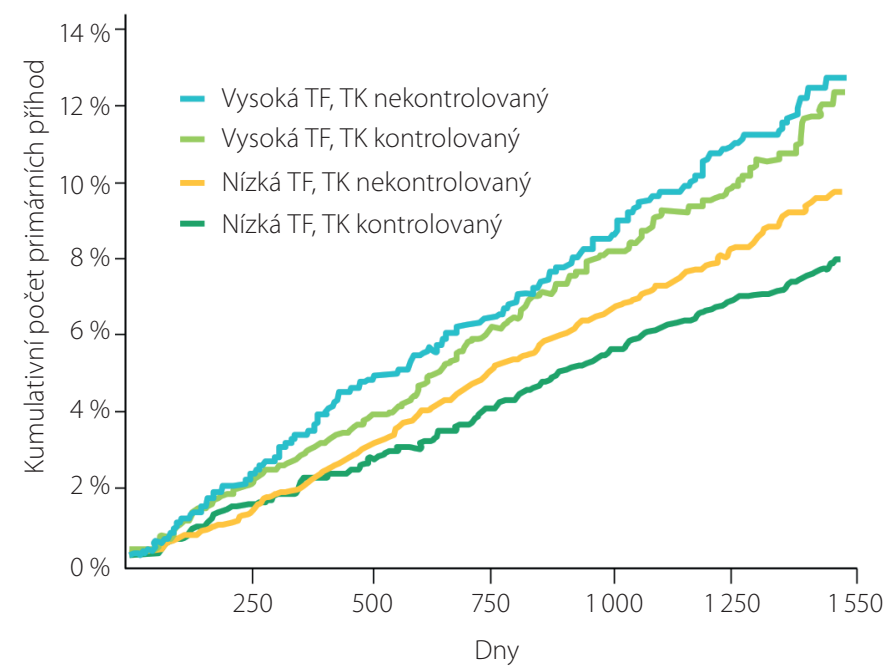

nostňována z důvodu lepší prognózy pacientů. Teprve jestliže jsou ACEI u daného pacienta kontraindikovány nebo je netoleruje, jsou na místě blokátory AT1 receptorů.

\section{Překážky dostatečné kompenzace $\mathrm{KV}$ rizikových faktorů}

Český průzkum provedený v roce 2018 (Hradec, 2019) ukázal, že farmakoterapie pacientů s ICHS je z hlediska predepsaných léků adekvátní. Většina jich užívá hypolipidemika, $\beta$-blokátory, antiagregancia a ACEI. Z pacientů léčených $\beta$-blokátory a ACEI má ale $44 \%$ krevní tlak $>140 / 90$ mm Hg a 33 \% tepovou frekvenci >80 tepů/min. To svědčí o nedostatečném dávkování jednotlivých prípravků. Navíc je průměrný počet tablet, které pacient denně užívá $>6$, což je vysoké číslo, které jednoznačně snižuje adherenci k léčbě, zejména při kompenzaci faktorů, které pacienta neobtěžují a jejichž zlepšení nevidí. Bylo zjištěno, že po 4 měsících po IM nedodržuje léčbu $22 \%$ pacientů a 2 roky po IM celých 64 \% (Kolandaivelu 2014). Nízká adherence k léčbě je přitom prríčinou 74\% zvýšení celkové mortality (Ho, 2008) a 32\% zvýšení koronární revaskularizace (Castellano, 2014). Prokázaný prínos na zvýšení adherence k léčbě má používání fixních kombinací účinných 
Obr. 3. Porovnání celkové a KV mortality u pacientů se STEMI (řešeno PCI s následnou implantací DES) prí léčbě $\beta$-blokátorem + ACEl vs. $\beta$-blokátorem + AT, blokátorem (Kim, 2019)

\section{Celková mortalita}

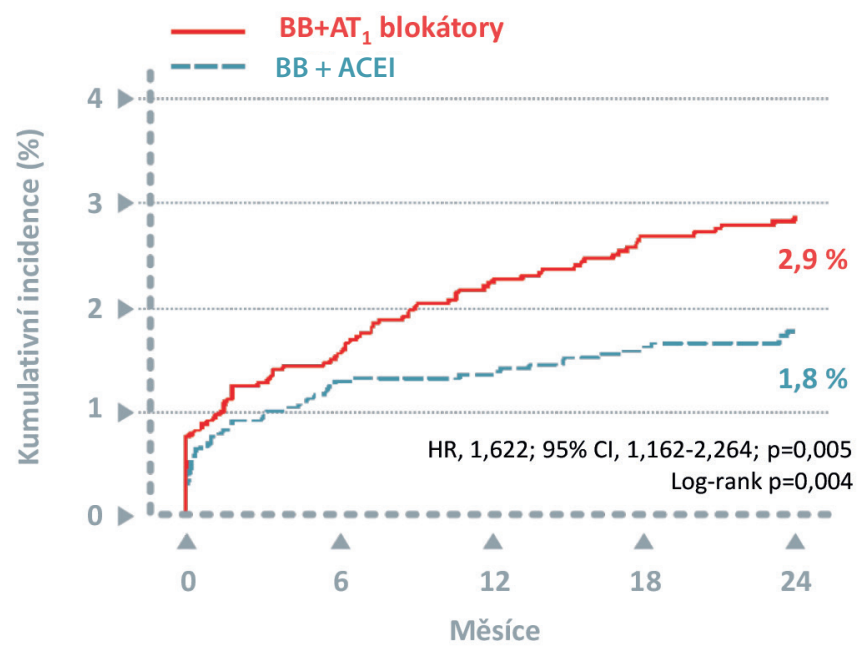

KV mortalita

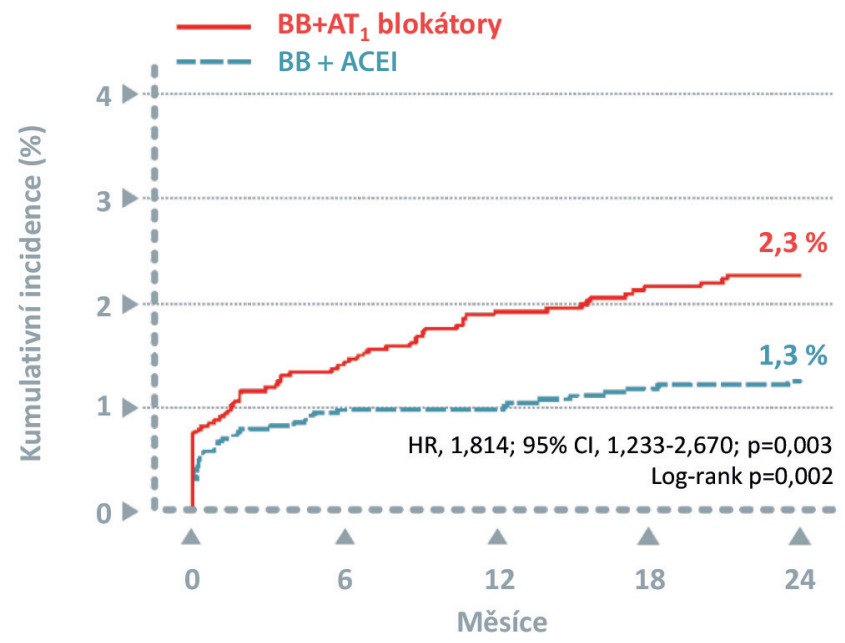

Obr. 4. Fixní kombinace zvyšuje compliance a zlepšuje prognózu pacientů (Simons, 2017)

Persistence na léčbě

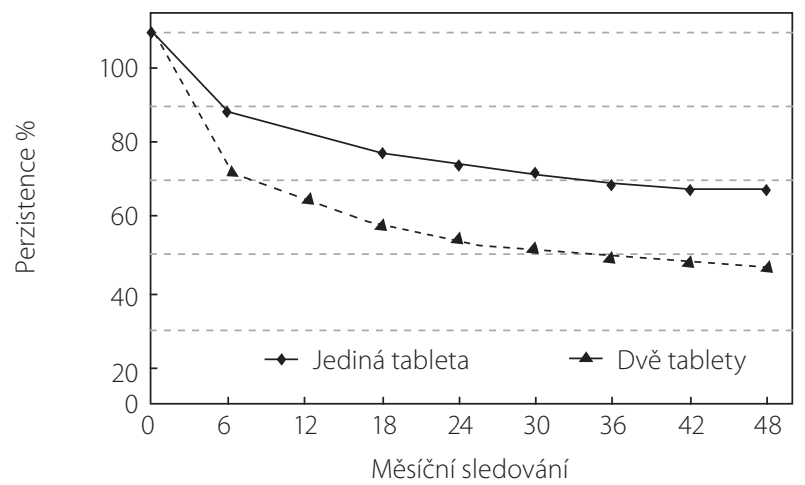

látek v jedné tabletě. Bylo doloženo, že fixní kombinace jsou spojeny s lepší prognózou pacientů, Obr. 4. (Simons, 2017). Tuto strategii uvádějí i doporučení ESC z roku 2017 pro léčbu pacientů se STEMI: „Strategie, jak zlepšit špatnou adherenci, je využití fixní kombinace nebo polypilu, zahrnující základní medikaci ke snížení KV rizika, a zároveň dávkování 1× denně." (Ibanez, 2018).

\section{Psychosociální faktory}

Nepríznivé psychosociální vlivy vedoucí k dlouhodobému stresu a úzkosti jsou spojeny se zvýšeným výskytem KV a onkologických onemocnění. V patofyziologii této spojitosti se uplatňuje zvýšený tonus sympatiku, snížený tonus parasympatiku, aktivace trombocytů, endoteliální dysfunkce, progrese aterosklerózy a hypertenze. Bylo např. prokázáno, že po ovdovění/ztrátě životního partnera dochází k poklesu variability tepové frekvence, což je ukazatel zvýšené aktivity sympatiku (Fagundes, 2018). Mechanismus vlivu emocí na tonus sympatiku přes limbický systém a jádra hypothalamu byl již popsán (Gianaros, 2009). Úzkost a deprese související se stresem se odrážejí např. v množství kortizolu ve slinách. A bylo zjištěno, že toto zvýšené množství kortizolu podporuje periodontální infekci a souvisí s rozvoje paradontózy (Nayak, 2013).

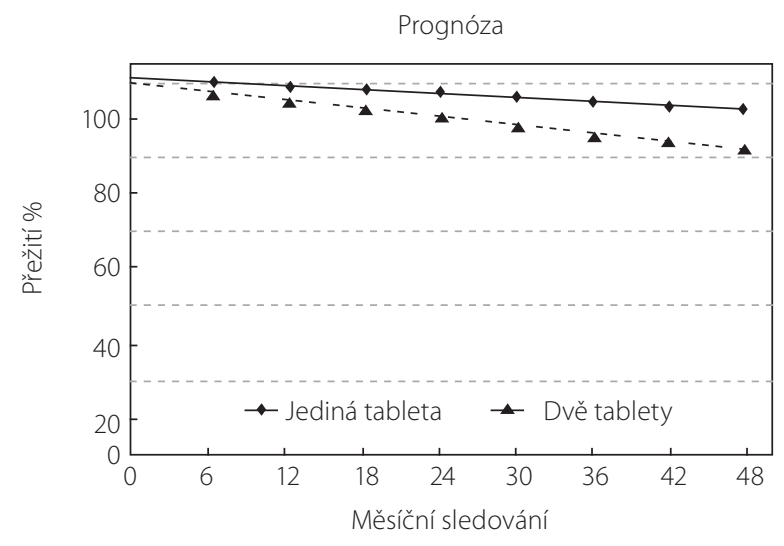

\section{Doporučení pro dlouhodobou léčbu pacientů po infarktu myokardu}

Doporučení z roku 2019 pro léčbu pacientů po prodělaném IM (Oštádal 2019) uvádějí v připadě hypertenze potřebu dosáhnout systolického tlaku krve $\leq 130$ mm Hg a diastolického tlaku krve >70 až <80 mm Hg (u pacientů starších 65 let 130-140/70-80 mm Hg). Po IM mají být upřednostňovány $\beta$-blokátory a blokátory RAAS, u pacientů se symptomatickou AP se doporučují $\beta$-blokátory nebo blokátory kalciových kanálů a u pacientů se srdečním selháním má léčba zahrnovat $\beta$-blokátor, blokátor RAAS a diuretikum nebo blokátor mineralokortikoidních receptorů. V hypolipidemické léčbě u vysoce rizikových pacientů s ACS je doporučena co nejvyšší tolerovaná dávka statinu bez ohledu na hladinu LDL cholesterolu. Po 4-6 týdnech by mělo být dosaženo hladiny LDL cholesterolu <1,4 mmol/l. Pokud není dosaženo cílové hodnoty při maximální tolerované dávce statinu, je doporučeno nasadit ezetimib, a jestliže ani tato kombinace po 4-6 týdnech nevede k dostatečné kompenzaci, je třeba odeslat pacienta do centra pro léčbu dyslipidemie pro nasazení inhibitoru PCSK9. Léčba PCSK9 je i přes subkutánní podávání dobře tolerována a spojena s př́znivou compliance ze strany pacientů.

Rovněž u všech pacientů s chronickými koronárními syndromy je doporučena maximální dávka statinů, popř. v kombinaci s ezetimibem a poté 
s inhibitorem PCSK9. Jestliže má nemocný s chronickým koronárním syndromem srdeční selhání, hypertenzi nebo diabetes, nebo má velmi vysoké KV riziko, má mít nasazenou také léčbu ACEl. Betablokátory jsou doporučeny v prípadě dysfunkce levé komory nebo systolického srdečního selhání a po prodělaném STEMI.

\section{Závěr}

Prognózu pacientů s ICHS určuje rozsah koronárního postižení, postižení funkce levé komory a jeho reverzibilita, kvalita sekundární

\section{LITERATURA}

1. Brugts JJ, et al. Eur Heart J. 2016; 37(suppl 1)339.

2. Castellano JM, Sanz G, Fernandez Ortiz A, Garrido E, Bansilal S, Fuster V. A polypill strategy to improve global secondary cardiovascular prevention: from concept to reality. J Am Coll Cardiol. 2014 Aug 12; 64(6): 613-621.

3. Fagundes CP, Murdock KW, LeRoy A, Baameur F, Thayer JF, Heijnen C. Spousal bereavement is associated with more pronounced ex vivo cytokine production and lower heart rate variability: Mechanisms underlying cardiovascular risk? Psychoneuroendocrinology. 2018; 93: 65-71. 4. Gianaros PJ, Sheu LK. A review of neuroimaging studies of stressor-evoked blood pressure reactivity: emerging evidence for a brain-body pathway to coronary heart disease risk. Neuroimage. 2009; 47(3): 922-936.

5. Ho PM, Magid DJ, Shetterly SM, Olson KL, Maddox TM, Peterson PN, Masoudi FA, Rumsfeld JS. Medication nonadherence is associated with a broad range of adverse outcomes in patients with coronary artery disease. Am Heart J. 2008; 155(4): 772-779.

6. Hradec J. Medicína po promoci 2019; 20: 1-7.

7. Chhatriwalla AK, Amin AP, Kennedy KF, House JA, Cohen DJ, Rao SV, Messenger JC, Marso SP; National Cardiovascular Data Registry. Association between bleeding events and in-hospital mortality after percutaneous coronary intervention. JAMA. 2013; 309(10): 1022-1029.

8. Cholesterol Treatment Trialists' (CTT) Collaboration, Baigent C, Blackwell L, Emberson J, Holland LE, Reith C, Bhala N, Peto R, Barnes EH, Keech A, Simes J, Collins R. Efficacy and safety of more intensive lowering of $L D L$ cholesterol: a meta-analysis of data from 170,000 participants in 26 randomised trials. Lancet. 2010; 376(9753): 1670-1681.

9. Ibanez B, James S, Agewall S, Antunes MJ, Bucciarelli-Ducci C, Bueno H, Caforio ALP, Crea F, Goudevenos JA, Halvorsen S, Hindricks G, Kastrati A, Lenzen MJ, Prescott E, Roffi M, Valgimigli M, Varenhorst C, Vranckx P, Widimský P; ESC Scientific Document Group. 2017 ESC Guidelines for the management of acute myocardial infarction in patients presenting with ST-segment elevation: The Task Force for the management of acute myocardial infarction in patients presenting with ST-segment elevation of the European Society of Cardiology (ESC). Eur Heart J. 2018; 39(2): 119-177.

10. Julius S, Palatini P, Kjeldsen SE, Zanchetti A, Weber MA, Mclnnes GT, Brunner HR, Mancia G, Schork MA, Hua TA, Holzhauer B, Zappe D, Majahalme S, Jamerson K, Koylan N. Usefulness of heart rate to predict cardiac events in treated patients with high-risk systemic hypertension. Am J Cardiol. 2012; 109(5): 685-692.

11. Kim YH, Her AY, Jeong MH, Kim BK, Lee SY, Hong SJ, Shin DH, Kim JS, Ko YG, Choi D, Hong prevence zahrnující nefarmakologické ovlivnění rizikových faktorů aterosklerózy (včetně psychického ladění pacienta), farmakoterapii s prokázaným príznivým vlivem na mortalitu ( $\beta$-blokátory, ACEl, statiny, ASA), dobrou adherenci k léčbě s využíváním kombinovaných preparátů a dosažení cílů pro sekundární prevenci (krevní tlak, lipidový profil, BMI), dále dobrá organizace péče o nemocné a také kvalitní osvěta ze strany lékařư pro zlepšení primární i sekundární prevence.

Pripravila MUDr. Zuzana Zafarová

MK, Jang Y. Comparison Between Beta-Blockers with Angiotensin-Converting Enzyme Inhibitors and Beta-Blockers with Angiotensin II Type I Receptor Blockers in ST-Segment Elevation Myocardial Infarction After Successful Percutaneous Coronary Intervention with Drug-Eluting Stents. Cardiovasc Drugs Ther. 2019; 33(1): 55-67.

12. Kolandaivelu K, Leiden BB, O'Gara PT, Bhatt DL. Non-adherence to cardiovascular medications. Eur Heart J. 2014; 35(46): 3267-3276.

13. Mundi S, Massaro M, Scoditti E, Carluccio MA, van Hinsbergh VWM, Iruela-Arispe ML, De Caterina R. Endothelial permeability, LDL deposition, and cardiovascular risk factors-a review. Cardiovasc Res. 2018; 114(1): 35-52.

14. Nayak SU, Nayak DG, Uppoor AS, Pai KK. Evaluation of cortisol levels in gingival crevicular fluid and saliva in anxious and non-anxious patients with chronic periodontitis. Dent Res J (Isfahan). 2013; 10(4): 474-481.

15. Neumann FJ, Sousa-Uva M, Ahlsson A, Alfonso F, Banning AP, Benedetto U, Byrne RA, Collet JP, Falk V, Head SJ, Jüni P, Kastrati A, Koller A, Kristensen SD, Niebauer J, Richter DJ, Seferovic PM, Sibbing D, Stefanini GG, Windecker S, Yadav R, Zembala MO; ESC Scientific Document Group. 2018 ESC/EACTS Guidelines on myocardial revascularization. Eur Heart J. 2019; 40(2): 87-165 16. Petr Oštádal P, Táborský M, Linhart A, Vrablík M, Češka R, Cífková R, Králíková E, Adámková V, Kvapil M, Jojko Z. Stručný souhrn doporučení pro dlouhodobou péči o nemocné po infarktu myokardu. Cor et Vasa. 2019; 61(5): 471-480.

17. Simons LA, Chung E, Ortiz M. Long-term persistence with single-pill, fixed-dose combination therapy versus two pills of amlodipine and perindopril for hypertension: Australian experience. Curr Med Res Opin. 2017; 33(10): 1783-1787.

18. Tsujita K, Sugiyama S, Sumida H, Shimomura H, Yamashita T, Yamanaga K, Komura N, Sakamoto K, Oka H, Nakao K, Nakamura S, Ishihara M, Matsui K, Sakaino N, Nakamura N, Yamamoto N, Koide S, Matsumura T, Fujimoto K, Tsunoda R, Morikami Y, Matsuyama K, Oshima S, Kaikita K, Hokimoto S, Ogawa H; PRECISE-IVUS Investigators. Impact of Dual Lipid-Lowering Strategy With Ezetimibe and Atorvastatin on Coronary Plaque Regression in Patients With Percutaneous Coronary Intervention: The Multicenter Randomized Controlled PRECISE-IVUS Trial. J Am Coll Cardiol. 2015; 66(5): 495-507.

19. Varenhorst C, Hasvold P, Johansson S, Janzon M, Albertsson P, Leosdottir M, Hambraeus K, James S, Jernberg T, Svennblad B, Lagerqvist B. Culprit and Nonculprit Recurrent Ischemic Events in Patients With Myocardial Infarction: Data From SWEDEHEART (Swedish Web System for Enhancement and Development of Evidence-Based Care in Heart Disease Evaluated According to Recommended Therapies). J Am Heart Assoc. 2018; 7(1): e007174. 